\title{
Polymorphisms of the human hexokinase II gene: lack of association with NIDDM and insulin resistance
}

\author{
M. Laakso ${ }^{1,2}$, M. Malkki ${ }^{1,2}$, P. Kekäläinen ${ }^{2}$, J.Kuusisto ${ }^{2}$, S.S.Deeb ${ }^{1}$ \\ ${ }^{1}$ Departments of Genetics and Medicine, University of Washington, Seattle, Washington, USA \\ ${ }^{2}$ Department of Medicine, Kuopio University Hospital, Kuopio, Finland
}

\begin{abstract}
Summary Skeletal muscle and adipose tissue hexokinase II is a promising candidate gene for non-insulin-dependent diabetes mellitus (NIDDM) and insulin resistance. Therefore, we investigated the association of alleles at four polymorphic loci in this gene with NIDDM and insulin resistance in 110 Finnish diabetic patients with NIDDM and in 97 Finnish control subjects with normal glucose tolerance and a negative family history of diabetes. The four polymorphic nucleotide substitutions (silent) in the coding region of the hexokinase II gene were: GAC 251 GAT (exon 7), AAC 692 AAT and CCG 736 CCC (exon 15), and CTG 766 CTA (exon 16). Allele frequencies of each of these polymorphisms did not dif-
\end{abstract}

fer between patients with NIDDM and control subjects. In addition, subjects who were homozygous for the less frequent allele of each of the four polymorphisms had a similar degree of insulin resistance, as determined by the euglycaemic clamp technique, as did the subjects who were homozygous for the common allele in both control subjects and in patients with NIDDM. In conclusion, polymorphisms in the hexokinase II gene are not associated with the risk of NIDDM or insulin resistance in the Finnish population. [Diabetologia (1995) 38: 617-622]

Key words Hexokinase II, polymorphism, NIDDM, insulin resistance.
A critical goal of current diabetes research is the identification of specific genetic defects that predispose to non-insulin-dependent diabetes mellitus (NIDDM). The aetiology of NIDDM is known only for a subset of well-defined families with maturity-onset diabetes of the young, where mutations in the glucokinase (hexokinase IV) gene, have been found [1]. These defects in glucokinase cause a mild form of insulin deficiency. Mutations in the genes encoding insulin [2], insulin receptor [3], and a mitochondrial tRNA [4] have been described.

Received: 22 August 1994 and in revised form: 22 November 1994

Corresponding author: Dr. M.Laakso, Department of Medicine, University of Kuopio, SF-70210 Kuopio, Finland Abbreviations: HKII, Hexokinase II; NIDDM, non-insulin-dependent diabetes mellitus; PCR, polymerase chain reaction; SSCP, single-strand conformation polymorphism; $R_{a}$, rate of glucose appearance; $R_{d}$, rate of glucose disappearance.
However, these mutations account for only a minor fraction of the aetiology of NIDDM and insulin resistance. :

Isoenzymes of hexokinase (I-IV) catalyse the first step of intracellular glucose metabolism, the conversion of glucose to glucose 6-phosphate [5]. Hexokinases I-III consist of a single polypeptide chain of $100 \mathrm{kDa}$, have a high affinity to glucose, and are subject to allosteric inhibition by glucose 6-phosphate. Hexokinase I is prevalent in brain, kidney, erythrocytes, and placenta, and is not stimulated by insulin [6]. Hexokinase II (HKII) is abundant in skeletal muscle and adipose tissue and is therefore a promising candidate gene for NIDDM and insulin resistance [6]. Insulin induces HKII expression which leads to enhanced glucose uptake by muscle cells. A decrease in skeletal muscle glucose 6-phosphate has been recently demonstrated in NIDDM [7]. Because glucose clearance involves the concerted action of GLUT4 and HKII, deficient action of the latter could explain these findings. 
Table 1. Primers for exons 7, 14-15 and 17 of the hexokinase II gene, size of the amplified fragment, enzyme digestion and fragment size for single strand conformation polymorphism (SSCP)

\begin{tabular}{|c|c|c|c|c|}
\hline no & Sequence $5^{\prime} \rightarrow 3^{\prime}$ & $\begin{array}{l}\text { Size of } \\
\text { amplified } \\
\text { fragment (bp) }\end{array}$ & $\begin{array}{l}\text { Cleavage } \\
\text { enzyme }\end{array}$ & $\begin{array}{l}\text { Restriction } \\
\text { fragments } \\
\text { (bp) }\end{array}$ \\
\hline $\begin{array}{l}7 \mathrm{~F} \\
7 \mathrm{R}\end{array}$ & $\begin{array}{l}\text { GCCGGAGCAGGCGTGTGC } \\
\text { CCAAGCCCACTCGCACAGG }\end{array}$ & 258 & None & None \\
\hline $\begin{array}{l}14 \mathrm{~F} \\
15 \mathrm{R}\end{array}$ & $\begin{array}{l}\text { GGTTCACCTGTGAACTGGGC } \\
\text { TCACTTGTTGCCATCCAGTCC }\end{array}$ & 478 & EcoO109 & $145,67,224,42$ \\
\hline $\begin{array}{l}16 \mathrm{~F} \\
16 \mathrm{R}\end{array}$ & $\begin{array}{l}\text { TGTCTCAACACATCCCTCCAC } \\
\text { CTTCAGTTTGTCTGCCAGTGAG }\end{array}$ & 284 & BstNI & 89,195 \\
\hline
\end{tabular}

We have recently determined the coding sequence and structure [8] of the human skeletal muscle HKII gene. We report in this article four previously unpublished nucleotide polymorphisms in the coding region of the HKII gene in patients with NIDDM and normal subjects and assess their association with insulin resistance.

\section{Subjects and methods}

Subjects. Altogether 110 Finnish patients with NIDDM were selected randomly from the epidemiological study [9] and from the diabetes clinic of the Kuopio University Hospital. The 97 subjects with normal glucose tolerance were selected from two previous population studies $[10,11]$. None of the control subjects had any chronic disease, any drug treatment which could influence carbohydrate metabolism, any abnormality in an oral glucose tolerance test (impaired glucose tolerance or diabetes according to the criteria of the World Health Organization [12], or hypertension (use of antihypertensive drugs, or systolic/diastolic blood pressure greater than 160/ $95 \mathrm{~mm} \mathrm{Hg}$ ). Each control subject had a negative family history of diabetes. All diabetic and control subjects had normal liver, kidney and thyroid function tests, and none had a history of excessive alcohol intake. Diabetic patients fulfilled the criteria for diabetes and NIDDM according to the criteria of the World Health Organization [12].

\section{Methods}

Study protocol. Every control subject participating in this study underwent an oral glucose tolerance test $(75 \mathrm{~g}$ of glucose in $10 \%$ solution). Oral glucose tolerance test was not performed on insulin-treated patients with NIDDM; instead the fasting Cpeptide level was used to exclude insulin-dependent diabetes. In each insulin-treated patient no history of ketoacidosis was recorded and their fasting C-peptide level exceeded $0.20 \mathrm{nmol} / 1$. A subset of diabetic $(n=23)$ and control subjects $(n=70)$ were admitted to the metabolic ward for 2 days. All these diabetic patients were treated with diet only or oral antidiabetic drugs.

Informed consent was obtained from all subjects after the purpose and potential risks of the study were explained to them. The protocol was approved by the Ethics Committee of the University of Kuopio and was in accordance with the Helsinki declaration.

Euglycaemic clamp. On day 2 after admission, the degree of insulin resistance was evaluated with the euglycaemic hyper- insulinaemic (insulin infusion of $80 \mathrm{mU} \cdot \mathrm{m}^{-2} \cdot \mathrm{min}^{-1}$ $\left(480 \mathrm{pmol} \cdot \mathrm{m}^{-2} \cdot \mathrm{min}^{-1}\right)$ in control subjects and $120 \mathrm{mU} \cdot \mathrm{m}^{-2}$. $\min ^{-1}\left(720 \mathrm{pmol} \cdot \mathrm{m}^{-2} \cdot \mathrm{min}^{-1}\right)$ in patients with NIDDM) clamp technique [13] as previously described in detail [14]. (3${ }^{3} \mathrm{H}$ )glucose was infused in patients with NIDDM as a primed $(40 \mu \mathrm{Ci})$ constant $(0.40 \mu \mathrm{Ci} / \mathrm{min})$ infusion for $180 \mathrm{~min}$ before initiating the insulin infusion. Blood glucose was clamped at $5.0 \mathrm{mmol} / \mathrm{l}$ for the next $180 \mathrm{~min}$ by infusing $20 \%$ glucose at varying rates according to blood glucose measurements performed at 5-min intervals (mean coefficient of variation of blood glucose was less than $4 \%$ both in patients with NIDDM and normal control subjects). In patients with NIDDM the rates of glucose appearance $\left(R_{a}\right)$ and disappearance $\left(R_{d}\right)$ during euglycaemic hyperinsulinaemic clamp studies were quantified from serum $\left(3-{ }^{3} \mathrm{H}\right)$ glucose specific activities and calculated using Steele's equations in their modified derivative form because the tracer exhibits non-steady-state kinetics under these conditions [15]. The rate of hepatic glucose output during the euglycaemic clamp was calculated as a difference between $R_{a}$ and exogenous glucose infusion rate. Negative numbers of hepatic glucose output, largely due to a model error emerging at high rates of glucose metabolism [16], were taken to indicate completely suppressed hepatic glucose output. The data were calculated for each 20-min interval; the mean value for the period 120-180 min was used to calculate the rates of whole body glucose uptake. In subjects with normal glucose tolerance $\left(3-{ }^{3} \mathrm{H}\right)$ glucose was not infused because hepatic glucose production is completely suppressed under these conditions according to our experience [14] and the findings of other investigators [17]. In control subjects the rate of whole body glucose uptake equals the glucose infusion rate.

Analytical methods. Blood glucose in the fasting state and during glucose clamp studies and plasma glucose in the oral glucose tolerance test were measured by the glucose oxidase method (Glucose Auto \& Stat HGA-1120 analyzer; Daiichi Co., Kyoto, Japan). Plasma insulin and C-peptide concentrations were determined by radioimmunoassay (Phadeseph Insulin RIA 100; Pharmacia Diagnostics AB, Uppsala, Sweden, and C-peptide of insulin by 125J RIA kit; Incstar Co., Stillwater, Minn., USA). $\left(3-^{3} \mathrm{H}\right)$ glucose specific activity in plasma was determined as previously described [18].

Single-stand conformation polymorphism (SSCP) analysis. DNA was prepared from peripheral blood leucocytes. Exons $7,14-15$, and 16 were amplified with the polymerase chain reaction (PCR) using primers shown in Table 1 and the products digested with the indicated restriction enzymes to obtain fragments of less than $258 \mathrm{bp}$. SSCP analysis was performed essentially as described by Orita et al. [19]. PCR amplification was conducted in a 15-20 $\mu \mathrm{l}$ volume containing $100 \mathrm{ng}$ genomic DNA, $7.5-10 \mathrm{pmol}$ of each primer, $10 \mathrm{mmol} / 1$ Tris- $\mathrm{HCl}$ 
(pH 8.3), $50 \mathrm{mmol} / 1 \mathrm{KCl}, 0.3-1$ units of Amplitaq DNA polymerase (Perkin-Elmer Cetus, Norwalk, Conn., USA), 1.5$2 \mu \mathrm{Ci}$ of (alpha- $\left.{ }^{32} \mathrm{P}\right) \mathrm{dCTP}$, dNTP $(62.5-200 \mu \mathrm{mol} / \mathrm{l})$, and $\mathrm{MgCl}_{2}(1-1.5 \mathrm{mmol} / \mathrm{l})$. PCR conditions were: denaturation at $94^{\circ} \mathrm{C}$ for $2-4 \mathrm{~min}$, followed by 35 cycles of denaturation at $92-$ $94^{\circ} \mathrm{C}$ for $45-60 \mathrm{~s}$, annealing at $62-66^{\circ} \mathrm{C}$ for $1 \mathrm{~min}$ and extension at $72^{\circ} \mathrm{C}$ for $45-60 \mathrm{~s}$ with a final extension at $72^{\circ} \mathrm{C}$ for $4 \mathrm{~min}$. The extension step was eliminated when the annealing temperature was over $64^{\circ} \mathrm{C}$. Prior to SSCP analysis PCR fragments from exons 14-15, and 16 were digested with the restriction enzymes given in Table 1 . After enzyme digestion PCR products were first diluted 3-10-fold with $0.1 \%$ SDS $10 \mathrm{mmol} / 1$ EDTA and then diluted $(1: 1)$ with loading dye mix ( $95 \%$ formamide, $20 \mathrm{mmol} / 1$ EDTA, $0.05 \%$ bromphenolblue, $0.05 \%$ xylene cyanol). After denaturation at $98^{\circ} \mathrm{C}$ for $3 \mathrm{~min}$, samples were immediately cooled on ice and $2 \mu \mathrm{l}$ of each sample were loaded onto a $5 \%$ (PCR products $\geq 200 \mathrm{bp}$ ) or $6 \%$ (PCR products $<200 \mathrm{bp}$ ) non-denaturating polyacrylamide gel (acrylamide / N,N'-methylene-bis-acrylamide ratio 49:1) containing $10 \%$ glycerol. The first 40 samples of NIDDM patients were run at two different gel temperatures: at $40 \mathrm{~W}$ with fan cooling for approximately $6 \mathrm{~h}$ at gel temperature of $27-28^{\circ} \mathrm{C}$, and at $45 \mathrm{~W}$ for approximately $4.5 \mathrm{~h}$ at a gel temperature of $38-40^{\circ} \mathrm{C}$. Because all polymorphisms were more clearly seen at the lower temperature, the rest of the samples were run only at $27-28^{\circ} \mathrm{C}$. These conditions have been shown to detect all known mutants of the lipoprotein lipase gene which have been found by direct sequencing in our laboratory $[20,21]$. The gel was dried and autoradiographed overnight at $-70^{\circ} \mathrm{C}$ with intensifying screens.

Direct sequencing. Genomic DNA from individuals with variant single strand conformers was used as a template in the amplification reaction as described above (total volume $100 \mu 1$ containing 70 pmol of each primer and 5 units of Amplitaq DNA polymerase). Amplified segments were purified by electrophoresis on a $1 \%$ low-melting-point agarose gel and directly sequenced using Sequenase (US Biochemicals, Cleveland, Ohio, USA) as previously described [22].

\section{Statistical analysis}

All calculations were performed using the SPSS/PC+ programs (SPSS Inc., Chicago, Ill., USA). Data are presented as mean \pm SEM. Statistical significance between the two groups was evaluated with the chi-squared test or unpaired Student's $t$-test when appropriate. Insulin concentrations were log-transformed for statistical analyses.
Table 2. Clinical characteristics of the study groups

\begin{tabular}{llc}
\hline & Control subjects & NIDDM subjects \\
\hline Sex (male/female) & $84 / 13$ & $55 / 55$ \\
Age (years) & $55 \pm 1$ & $63 \pm 1$ \\
$\begin{array}{l}\text { Body mass index } \\
\left(\mathrm{kg} / \mathrm{m}^{2}\right)\end{array}$ & $26.8 \pm 0.3$ & $30.3 \pm 0.5$ \\
$\begin{array}{l}\text { Fasting glucose } \\
\text { (mmol/l) }\end{array}$ & $5.5 \pm 0.1$ & $9.2 \pm 0.3$ \\
$\begin{array}{l}\text { Duration of diabetes } \\
\text { (years) }\end{array}$ & - & $8 \pm 1$ \\
$\begin{array}{l}\text { Age of onset of } \\
\text { diabetes (years) }\end{array}$ & - & $54 \pm 1$ \\
$\begin{array}{l}\text { Treatment for } \\
\text { diabetes (\%) }\end{array}$ & & \\
$\quad$ Diet & & \\
Oral drugs & - & 49 \\
Insulin & - & 29 \\
\hline
\end{tabular}

\section{Results}

Clinical characteristics of the study groups. Table 2 gives clinical and metabolic characteristics of study subjects who participated in the initial and additional screening. The mean age of diabetic patients was 63 years. These diabetic patients represented typical Finnish patients with NIDDM. They were obese, hyperglycaemic and the mean age of onset of diabetes was over 50 years.

Polymorphisms. Four of the five polymorphisms of the HKII gene which were found were used in the analyses. Exon 7 polymorphism in codon 251 was a silent substitution GAC $\rightarrow$ GAT (Fig. 1). In exon 15 two silent substitutions were found in codon 692 $(\mathrm{AAC} \rightarrow \mathrm{AAT})$ (Fig. 2) and in codon 736 (CCG $\rightarrow \mathrm{CCC}$ ) (Fig. 1). These substitutions abolish the MaeII and XmaI restriction sites, respectively. Exon 16 polymorphism was a silent substitution $\mathrm{CTG} \rightarrow \mathrm{CTA}$ in codon 766 . We also found a silent substitution in exon 4 (CAA $\rightarrow$ CAT in codon 142) but we did not use this substitution in statistical analyses because the frequency distribution of less frequent and common alleles of this polymorphism was identical

\section{EXON 7 (GAC 251 GAT)}

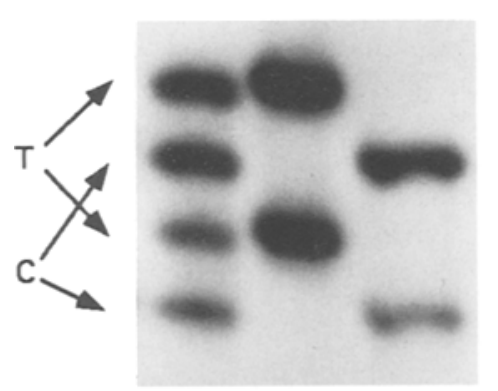

EXON 16 (CTG 766 CTA)

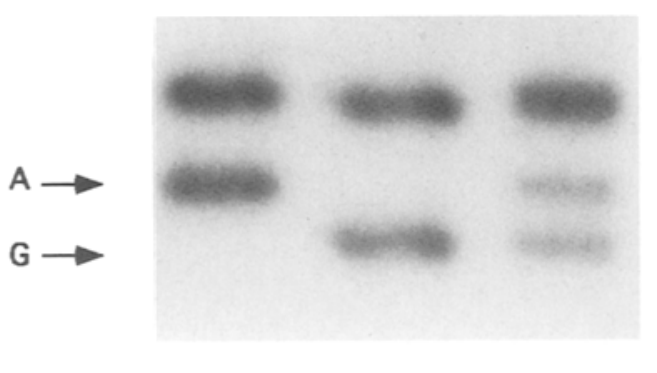

Fig.1. Single strand conformation analysis of exon 7 and 17 polymorphisms of the hexokinase II gene 


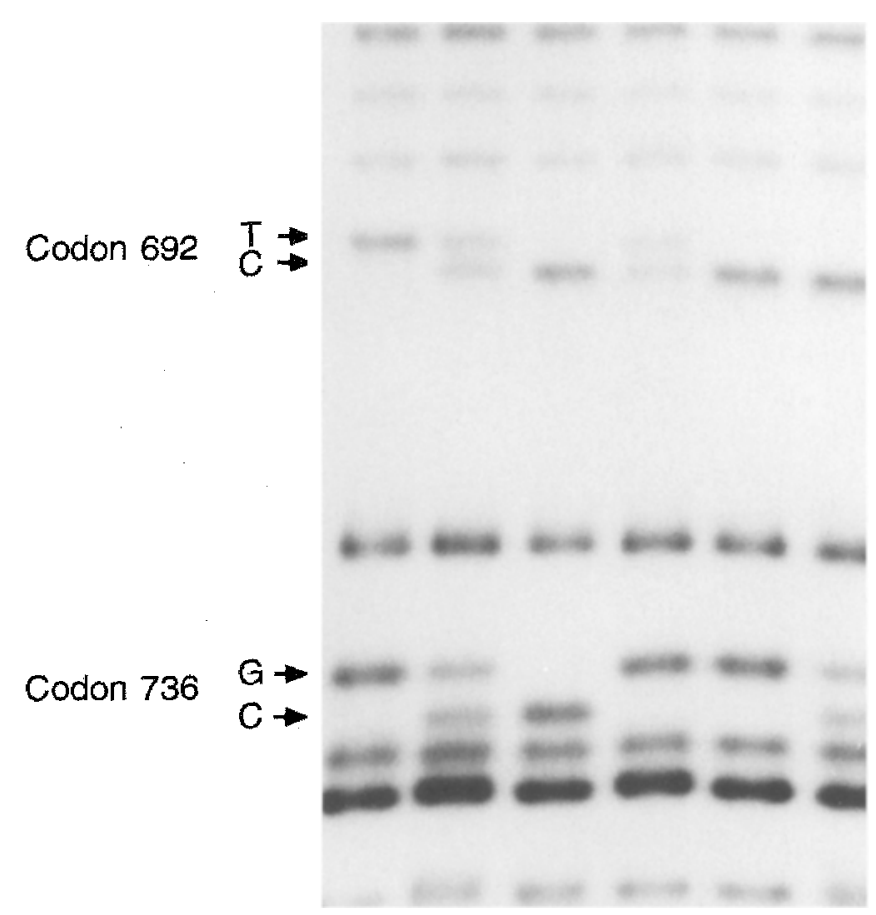

Fig. 2. Single strand conformation analysis of exon 15 polymorphism of the hexokinase II gene

Table 3. Allele frequencies of exon 7,15 and 16 polymorphisms of the hexokinase II gene in control subjects and in patients with NIDDM

\begin{tabular}{lll}
\hline & \multicolumn{2}{l}{ Less frequent allele frequency (\%) } \\
\cline { 2 - 3 } Nucleotide substitution $^{\mathrm{a}}$ & $\begin{array}{l}\text { Control } \\
(n=97)\end{array}$ & $\begin{array}{l}\text { NIDDM } \\
(n=110)\end{array}$ \\
\hline GAC 251 GAT & 25.3 & 21.4 \\
AAC 692 AAT & 45.4 & 39.1 \\
CCG 736 CCC & 30.9 & 37.7 \\
CTG 766 CTA & 26.3 & 28.2 \\
\hline
\end{tabular}

${ }^{a}$ Less frequent allele given to the right of the codon number None of the comparisons between the two groups was statistically significant

to that of the exon 7 polymorphism. Table 3 shows allele frequencies of these polymorphisms in control subjects and patients with NIDDM. No statistical significant differences between these two groups were found. Similarly, the frequency of 21 different combinations of these four polymorphisms did not differ between control subjects and patients with NIDDM (Table 4). The most frequent genotypic combination was heterozygous for codons $251(\mathrm{C} / \mathrm{T})$ and $692(\mathrm{C} /$ $\mathrm{T})$ and homozygous for codons $736(\mathrm{G})$ and $766(\mathrm{G})$. It was found in $24.7 \%$ of control subjects and in $19.1 \%$ of patients with NIDDM.

Insulin levels and insulin resistance associated with different polymorphisms. Table 5 shows insulin levels in a oral glucose tolerance test in control subjects and in patients with NIDDM. Insulin as well as C-
Table 4. Different combinations of genotypes at polymorphic loci in exons 7, 15 and 16 of the hexokinase II gene and their frequency in control subjects and in patients with NDDDM

\begin{tabular}{|c|c|c|c|c|c|}
\hline \multirow{2}{*}{$\begin{array}{l}\text { Codon } \\
251\end{array}$} & \multirow{2}{*}{$\begin{array}{l}\text { Codon } \\
692\end{array}$} & \multirow{2}{*}{$\begin{array}{l}\text { Codon } \\
736\end{array}$} & \multirow{2}{*}{$\begin{array}{l}\text { Codon } \\
766\end{array}$} & \multicolumn{2}{|c|}{ Frequency (\%) } \\
\hline & & & & $\begin{array}{l}\text { Control } \\
\text { subjects } \\
(n=97)\end{array}$ & $\begin{array}{l}\text { NIDDM } \\
\text { subjects } \\
(n=110)\end{array}$ \\
\hline $\mathrm{C}$ & $\mathrm{T}$ & $\mathrm{G}$ & $\mathrm{G}$ & 15.5 & 10.9 \\
\hline $\mathrm{C}$ & $\mathrm{C} / \mathrm{T}$ & $G$ & $\mathrm{G}$ & 0 & 1.8 \\
\hline $\mathrm{C} / \mathrm{T}$ & C & $\mathrm{G}$ & $\mathrm{G}$ & 0 & 0.9 \\
\hline $\mathrm{C} / \mathrm{T}$ & $\mathrm{C} / \mathrm{T}$ & $\mathrm{G}$ & $\mathrm{G}$ & 24.7 & 19.1 \\
\hline $\mathrm{T}$ & C & $\mathrm{G}$ & G & 4.1 & 3.6 \\
\hline $\mathrm{T}$ & $\mathrm{C} / \mathrm{T}$ & $\mathrm{G}$ & $\mathrm{G}$ & 1.0 & 0.9 \\
\hline C & $\mathrm{C} / \mathrm{T}$ & $\mathrm{G} / \mathrm{C}$ & $\mathrm{G}$ & 3.1 & 8.2 \\
\hline $\mathrm{C} / \mathrm{T}$ & $\mathrm{C}$ & $\mathrm{G} / \mathrm{C}$ & $\mathrm{G}$ & 4.1 & 5.5 \\
\hline $\mathrm{C}$ & $\mathrm{C}$ & $\mathrm{C}$ & A & 3.1 & 8.2 \\
\hline $\mathrm{C}$ & $\mathrm{C} / \mathrm{T}$ & $\mathrm{C}$ & A & 1.0 & 0 \\
\hline C & $\mathrm{C} / \mathrm{T}$ & $\mathrm{G} / \mathrm{C}$ & A & 1.0 & 2.7 \\
\hline C & $\mathrm{T}$ & $\mathrm{G}$ & $\mathrm{G} / \mathrm{A}$ & 2.1 & 1.8 \\
\hline $\mathrm{C}$ & $\mathrm{C}$ & $\mathrm{C}$ & $\mathrm{G}$ & 0 & 2.7 \\
\hline C & C & C & $\mathrm{G} / \mathrm{A}$ & 5.2 & 5.5 \\
\hline $\mathrm{C}$ & $\mathrm{C}$ & $\mathrm{G} / \mathrm{C}$ & $\mathrm{G}$ & 0 & 0.9 \\
\hline C & $\mathrm{C} / \mathrm{T}$ & $\mathrm{G} / \mathrm{C}$ & $\mathrm{G} / \mathrm{A}$ & 23.7 & 17.3 \\
\hline $\mathrm{ClT}$ & $\mathrm{C}$ & $\mathrm{G} / \mathrm{C}$ & $\mathrm{G} / \mathrm{A}$ & 10.3 & 6.4 \\
\hline $\mathrm{C} / \mathrm{T}$ & $\mathrm{C} / \mathrm{T}$ & $\mathrm{G} / \mathrm{C}$ & $\mathrm{G} / \mathrm{A}$ & 1.0 & 0 \\
\hline $\mathrm{C} / \mathrm{T}$ & $\mathrm{T}$ & $\mathrm{G}$ & $\mathrm{G} / \mathrm{A}$ & 0 & 0.9 \\
\hline $\mathrm{C} / \mathrm{T}$ & $\mathrm{C} / \mathrm{T}$ & $\mathrm{G}$ & $\mathrm{G} / \mathrm{A}$ & 0 & 0.9 \\
\hline $\mathrm{C}$ & $\mathrm{C}$ & $\mathrm{G} / \mathrm{C}$ & $\mathrm{G} / \mathrm{A}$ & 0 & 1.8 \\
\hline
\end{tabular}

None of the comparisons between the two groups was statistically significant

peptide and glucose levels (data not shown) did not differ between the subjects who were homozygous for the less frequent allele and those who were homozygous for the common allele in each codon either in control subjects or in patients with NIDDM. Similarly, polymorphisms in codons $251,692,736$ and 766 were not associated with a higher degree of insulin resistance in control subjects or in patients with NIDDM (Table 5).

\section{Discussion}

The muscle and adipose tissue HKII catalyses the phosphorylation of glucose to glucose 6-phosphate, and therefore plays the key role in glucose metabolism in these insulin-sensitive tissues. Therefore, it is a promising candidate gene for NIDDM and insulin resistance.

In the present study we determined the association of four nucleotide sequence polymorphisms located in exons 7,15 , and 16 of the HKII gene with insulin levels and insulin resistance in patients with NIDDM and in subjects with normal glucose tolerance and a negative family history of diabetes. The allele frequencies of each of the polymorphisms did not differ between control subjects and patients with NIDDM. Furthermore, the frequency of different combinations of the genotypes at these polymorphisms was 
Table 5. Insulin concentrations in an oral glucose tolerance test and whole body glucose uptake during the euglycaemic clamp in subjects who were homozygous for the less frequent and common allele of different polymorphisms of the hexokinase II gene by glucose tolerance status (number of subjects in parentheses)

\begin{tabular}{|c|c|c|c|c|}
\hline & \multicolumn{3}{|c|}{ Insulin $(\mathrm{pmol} / \mathrm{l})$} & \multirow{2}{*}{$\begin{array}{l}\text { Whole body glucose up- } \\
\text { take }\left(\mu \mathrm{mol} \cdot \mathrm{kg}^{-1} \cdot \mathrm{min}^{-1}\right)\end{array}$} \\
\hline & Fasting & $1 \mathrm{~h}$ & $2 \mathrm{~h}$ & \\
\hline $\begin{array}{l}\text { Subjects with no } \\
\text { Codon } 251 \\
\text { Homoz. for C } \\
\text { Homoz. for } \mathrm{T}\end{array}$ & $\begin{array}{l}\text { cose tolerance } \\
56 \pm 5(53) \\
57 \pm 19 \text { (5) }\end{array}$ & $\begin{array}{l}479 \pm 59(53) \\
524 \pm 186(5)\end{array}$ & $\begin{array}{l}238 \pm 34(53) \\
296 \pm 123(5)\end{array}$ & $\begin{array}{l}57.1 \pm 2.4(36) \\
50.2 \pm 4.2(4)\end{array}$ \\
\hline $\begin{array}{l}\text { Codon } 692 \\
\text { Homoz. for } \mathrm{C} \\
\text { Homoz. for } \mathrm{T}\end{array}$ & $\begin{array}{l}48 \pm 7(26) \\
56 \pm 6(17)\end{array}$ & $\begin{array}{l}414 \pm 87(26) \\
436 \pm 69(17)\end{array}$ & $\begin{array}{l}186 \pm 35(26) \\
253 \pm 47(17)\end{array}$ & $\begin{array}{l}57.5 \pm 3.1(20) \\
59.7 \pm 3.7(12)\end{array}$ \\
\hline $\begin{array}{l}\text { Codon } 736 \\
\text { Homoz. for } \mathrm{G} \\
\text { Homoz. for } \mathrm{C}\end{array}$ & $\begin{array}{l}51 \pm 4(46) \\
47 \pm 17 \quad(9)\end{array}$ & $\begin{array}{l}424 \pm 43(46) \\
502 \pm 212(9)\end{array}$ & $\begin{array}{l}225 \pm 28(46) \\
163 \pm 65(9)\end{array}$ & $\begin{array}{l}57.5 \pm 1.8(35) \\
59.0 \pm 6.6(6)\end{array}$ \\
\hline $\begin{array}{l}\text { Codon } 766 \\
\text { Homoz. for } \mathrm{G} \\
\text { Homoz. for A }\end{array}$ & $\begin{array}{l}51 \pm 4(51) \\
38 \pm 6(5)\end{array}$ & $\begin{array}{l}436 \pm 41(51) \\
321 \pm 70(5)\end{array}$ & $\begin{array}{l}226 \pm 25(51) \\
176 \pm 67(5)\end{array}$ & $\begin{array}{l}57.1 \pm 1.8(37) \\
63.0 \pm 0.3(2)\end{array}$ \\
\hline $\begin{array}{l}\text { Patients with } \\
\text { Codon } 251 \\
\text { Homoz. for } \mathrm{C} \\
\text { Homoz. for } \mathrm{T}\end{array}$ & $\begin{array}{l}134 \pm 12(52) \\
164 \pm 75(3)\end{array}$ & $\begin{array}{l}467 \pm 55(37) \\
202 \pm 19(2)\end{array}$ & $\begin{array}{l}531 \pm 77(37) \\
219 \pm 74 \quad(2)\end{array}$ & $\begin{array}{l}27.5 \pm 2.4(18) \\
-\end{array}$ \\
\hline $\begin{array}{l}\text { Codon } 692 \\
\text { Homoz. for C } \\
\text { Homoz. for } \mathrm{T}\end{array}$ & $\begin{array}{l}142 \pm 23(31) \\
140 \pm 18(11)\end{array}$ & $\begin{array}{l}502 \pm 92(21) \\
475 \pm 153(7)\end{array}$ & $\begin{array}{l}607 \pm 115(21) \\
544 \pm 206(7)\end{array}$ & $\begin{array}{l}25.5 \pm 3.9 \\
19.4 \pm 6.2(7)\end{array}$ \\
\hline $\begin{array}{l}\text { Codon } 736 \\
\text { Homoz. for } \mathrm{G} \\
\text { Homoz. for } \mathrm{C}\end{array}$ & $\begin{array}{l}132 \pm 13(34) \\
118 \pm 17(13)\end{array}$ & $\begin{array}{l}538 \pm 108(19) \\
465 \pm 110(9)\end{array}$ & $\begin{array}{l}563 \pm 114(19) \\
644 \pm 205 \quad(9)\end{array}$ & $\begin{array}{l}28.3 \pm 4.6 \\
21.2 \pm 3.8\end{array}$ \\
\hline $\begin{array}{l}\text { Codon } 766 \\
\text { Homoz. for } \mathrm{G} \\
\text { Homoz. for } \mathrm{A}\end{array}$ & $\begin{array}{l}138 \pm 12(47) \\
107 \pm 17(7)\end{array}$ & $\begin{array}{l}548 \pm 94(27) \\
353 \pm 82(5)\end{array}$ & $\begin{array}{l}569 \pm 101(27) \\
488 \pm 146 \quad(5)\end{array}$ & $\begin{array}{l}29.4 \pm 3.2(10) \\
25.9 \pm 8.0\end{array}$ \\
\hline
\end{tabular}

also similar in these groups. Our results were based on a significant number of normal subjects and patients with NIDDM who were representative of nondiabetic and diabetic population living in the Kuopio University Hospital area. Finally, hyperinsulinaemia during an oral glucose tolerance test or insulin resistance evaluated by the euglycaemic hyperinsulinaemic clamp were not associated with the less frequent allele of each of the four polymorphisms. These results were based both on control subjects and patients with NIDDM although the clamp data on diabetic patients was based rather on a limited number of cases.

Recently Lehto et al. [23] have reported a simple tandem repeat DNA polymorphism in HKII which was predicted to be in intron 13. Preliminary linkage studies in two large Finnish families with classic lateonset NIDDM showed that HKII is not tightly linked with diabetes in these families, although log of the odds scores were not reported. Our results of the four polymorphisms in the coding region of the HKII gene in control subjects and patients with NIDDM are in accordance with these results. However, these results do not exclude the possibility of finding mutations in the HKII gene in a small subset of patients with NIDDM. Further studies based on the molecular scanning of all exons of the HKII gene are in progress to investigate this possibility.

Acknowledgements. This study was supported by a grant from the Medical Research Council of the Academy of Finland, and by Public Health Service Grant HL-30086.

\section{References}

1. Froguel P, Zouali H, Vionnet N et al. (1993) Familial hyperglycemia due to mutations in glucokinase. Definition of a subtype of diabetes mellitus. New Engl J Med 328: 697-702

2. Steiner DF, Tager HS, Chan J, Nanjo K, Sanke T, Rubenstein AH (1990) Lessons learned from molecular biology of insulin-gene mutations. Diabetes Care 13: 600-609

3. Taylor SI (1992) Lilly Lecture: molecular mechanisms of insulin resistance. Lessons from patients with mutations in the insulin-receptor gene. Diabetes 41: 1473-1490

4. Ballinger SW, Shoffner JM, Hedaya EV et al. (1992) Maternally transmitted diabetes and deafness associate with a $10.4 \mathrm{~kb}$ mitochondrial DNA deletion. Nature Genetics 1: $11-15$

5. Thelen AP, Wilson JE (1991) Complete amino acid sequence of the type $I$ isoenzyme of rat hexokinase, deducted from the cloned cDNA: comparison with a hexokinase from Novikoff ascites tumor. Arch Biochem Biophys 286: 645-651 
6. Printz RL, Koch S, Potter LR et al. (1993) Hexokinase II mRNA and gene structure, regulation by insulin, and evolution. J Biol Chem 268: 5209-5219

7. Shulman GI, Rothman DL, Jue T, Stein P, DeFronzo RA, Shulman RG (1990) Quantitation of muscle glycogen synthesis in normal subjects and subjects with non-insulindependent diabetes by ${ }^{13} \mathrm{C}$ nuclear magnetic resonance spectroscopy. N Engl J Med 322: 223-229

8. Malkki M, Laakso M, Deeb SS (1994) Structure of the human hexokinase II gene. Biochem Biophys Res Comm 205: 490-496

9. Sarlund H, Laakso M, Voutilainen E, Penttilä I, Pyörälä K (1991) Familial aggregation of non-insulin-dependent diabetes and coronary heart disease are accompanied by different effects on serum lipids, lipoproteins and apolipoproteins. Atherosclerosis 31: 17-29

10. Laakso M, Rönnemaa T, Pyörälä K, Kallio V, Puukka P, Penttilä I (1988) Atherosclerotic vascular disease and its risk factors in non-insulin-dependent diabetic and nondiabetic subjects in Finland. Diabetes Care 11: 449-463

11. Laakso M, Sarlund H. Salonen R et al. (1991) Asymptomatic atherosclerosis and insulin resistance. Arterioscl Thromb 11: 1068-1076

12. World Health Organization (1985) Diabetes mellitus: report of a WHO Study Group. Geneva, World Health Org (Tech Rep Ser, no. 727)

13. DeFronzo RA, Tobin JD, Andres R (1979) Glucose clamp technique: a method for quantifying insulin secretion and resistance. Am J Physiol 237: E214-E223

14. Karhapää P, Uusitupa M, Voutilainen E, Laakso M (1992) Effects of bezafibrate on insulin sensitivity and glucose tol- erance in subjects with combined hyperlipidemia. Clin Pharmacol Ther 52: 620-626

15. Steele R (1959) Influence of glucose loading and of injected insulin on hepatic glucose production. Ann NY Acad Sci 82: $420-430$

16. Cobelli C, Mari A, Ferrannini E (1987) Non-steady state: error analysis of Steele's model and development for glucose kinetics. Am J Physiol 252: E679-E689

17. Bergman RN, Finegood DT, Ader M (1985) Assessment of insulin sensitivity in vivo. Endocrinol Rev 5: 45-86

18. Laakso M, Uusitupa M, Takala J, Majander H, Reijonen T, Penttilä I (1988) Effects of hypocaloric diet and insulin therapy on metabolic control and mechanisms of hyperglycemia in obese non-insulin-dependent diabetic subjects. Metabolism 37: 1092-1100

19. Orita M, Suzuki Y, Sekiya T, Hayashi K (1989) Rapid and sensitive detection of point mutations and DNA polymorphisms using the polymerase chain reaction. Genomics 5: 874-879

20. Reina M, Brunzell JD, Deeb SS (1992) Molecular basis of familial chylomicronemia: mutations in the lipoprotein lipase and apolipoprotein C genes. J Lipid Res 33: 1823-1832

21. Nevin DN, Brunzell JD, Deeb SS (1994) The LPL gene in individuals with familial combined hyperlipidemia and decreased LPL activity. Arterioscl Thromb 14: 869-873

22. Kretz KA, Carson GS, O'Brien JS (1989) Direct sequencing from low-melt agarose with Sequenase. Nucl Acid Res 17: 5864

23. Lehto M, Xiang K, Stoffel M et al. (1993) Human hexokinase II: localization of the polymorphic gene to chromosome 2. Diabetologia 36: 1299-1302 